\title{
Biotic factors damaging forest stands in Gornata Koria and Chuprene Reserves in Western Balkan Range, Bulgaria
}

\author{
Margarita Georgieva ${ }^{1}$, Georgi Georgiev ${ }^{1}$, Plamen Mirchev ${ }^{1}$, \\ Gergana Zaemdzhikova ${ }^{1}$, Danail Doychev ${ }^{2}$, Sonya Bencheva², Nikolay Zafirov ${ }^{2}$, \\ Stelian Dimitrov ${ }^{3}$, Martin Iliev ${ }^{3}$, Vladislav Trenkin ${ }^{4}$
}

${ }^{1}$ Forest Research Institute - Bulgarian Academy of Sciences, Sofia

${ }^{2}$ University of Forestry, Sofia

${ }^{3}$ Sofia University 'St. Kliment Ohridski'

${ }^{4}$ Geographica Ltd., Sofia

Corresponding author: Margarita Georgieva (margaritageorgiev@gmail.com)

Academiceditor:Ivaylo Markoff|Received 28 October 2020|Accepted 02 November 2021|Published 19 November 2021

Citation: Georgieva, M., G. Georgiev, P. Mirchev, G. Zaemdzhikova, D. Doychev, S. Bencheva, N. Zafirov, S. Dimitrov, M. Iliev, V. Trenkin (2021) Biotic factors damaging forest stands in Gornata Koria and Chuprene Reserves in Western Balkan Range, Bulgaria, Silva Balcanica 22(2): 91-102. https://doi.org/10.3897/silvabalcanica.22.e77233

\begin{abstract}
Assessment and monitoring of health status in deteriorated forest stands in Gornata Koria and Chuprene Reserves in Western Balkan Range (Bulgaria) were conducted in 2017. An integrated approach (based on remote sensing technologies and terrestrial validation) was applied. A series of subsequent terrain observations were carried out in both protected areas mainly in dead or in poor health status stands. As a result, sixteen insect species were identified in Gornata Koria and nine pests in Chuprene Reserves. The predominant number of pests included bark beetles and weevils (Curculionidae), longhorn beetles (Cerambycidae), etc. Attacks caused by the European bark beetle (Ips typographus) formed the main disturbance in the Norway spruce forests in both reserves. Ten parasitic and ten saprophytic fungi were identified in the stands of the Norway spruce (Picea abies), silver fir (Abies alba) and European beech (Fagus sylvatica). Among the parasitic fungi, six species were identified as destructive (Armillaria sp., Heterobasidion annosum, Fomitopsis pinicola, Fomes fomentarius, Ramaria flava and Pholiota squarrosa).
\end{abstract}

\section{Keywords}

protected areas, health condition, insect pests, fungal pathogens

Copyright Margarita Georgieva. This is an open access article distributed under the terms of the Creative Commons Attribution License (CC BY 4.0), which permits unrestricted use, distribution, and reproduction in any medium, provided the original author and source are credited. 


\section{Introduction}

In recent decades, deterioration of forest stands due to long periods of drought and abnormal climatic phenomena has occurred. The gradual change in the environmental conditions has altered the ecology of host tree species, the harmful effect of biotic agents and their vectors that cause the disturbance in forest stands. In most cases this is a consequence of a combination of adverse climatic conditions with harmful biotic factors, mainly insect pests and fungal diseases (Foley et al., 2005; Trumbore et al., 2015).

Biotic factors cause changes in forest structure and function, and influence the species biodiversity (Edmonds et al., 2011). Examining pest and disease occurrence and related stress factors, the regional extend of infestations and interactions among hosts distribution, stress factors and biotic agents could be clarified (Holdenrieder et al., 2004).

Outbreaks of bark beetles are known to be the proximate cause of tree mortality, affecting forests already stressed by drought and chronically weakened by pathogens and other agents. Among the xylophagous pests trophically related to the Norway spruce (Picea abies (L.) Karst.), the most aggressive is the European bark beetle (Ips typographus L.). This pest is widespread in Europe, Northern Asia (China, Korea, Japan, and Russia) and Minor Asia (CABI, 2021). Trees under stress by abiotic (drought, wind, snow) or biotic (defoliating insects, fungal diseases) factors are predisposed to the pest attacks. The pest outbreaks after windstorms or droughts are likely to trigger dieback of host trees on a large scale within the following several years (Angst et al., 2012).

In the context of climate change, fungal pathogens are playing an increasingly crucial role in deteriorating the health status of forest vegetation. Pathological processes in forest ecosystems are most often the result of a complex impact of abiotic and biotic factors and should be considered together. The fungal pathogen Heterobasidion annosum (Fr.) Bref. is a major cause of root and stem rot in the coniferous stands of the Northern Hemisphere (Hodges, 1969), causing large economic losses in many countries.

The remote sensing data taken in forest stands provide useful information for detection the deterioration mainly caused by bark beetles and root rot disease outbreaks (Dimitrov et al., 2018). Data from images are used for monitoring of environmental variables, such as size of damaged area, tendency to expand the affected areas, patterns of disease outbreaks, etc. Not all of the biotic agents could be detected by remote sensing images, so terrain verifications have to be conducted in order to establish and confirm the main traits for the health of protected forest ecosystems.

In 2017, remote sensing technologies for exploring the deteriorated areas in Gornata Koria and Chuprene Reserves were applied (Dimitrov et al., 2018). The aim of this study was to present the results from the terrestrial validations of captured areas and to identify the complex of the main biotic stressors responsible for the deterioration of forest stands in both reserves in the West Balkan Range. 


\section{Material and methods}

The studies on the health condition of protected forest stands were carried out as a part of activities included in the Management plans of Gornata Koria Reserve and Chuprene Biosphere Reserve. Both reserves were created to preserve the natural coniferous forests in the Western Balkan Range in Bulgaria (Fig. 1). Gornata Koria was established in 1968 in Berkovska Mountain, and Chuprene Reserve - in 1973 in Chiprovska Mountain. In the period 1977-2021, the Chuprene Reserve was included in the UNESCO list of Biosphere Reserves under the Human and Biosphere Program. Assessment and monitoring of the health status of the Norway spruce (Picea abies), silver fir (Abies alba Mill.) and European beech (Fagus sylvatica L.) natural stands in Gornata Koria and Chuprene Reserves were carried out in 2017.

Field expeditions for terrestrial observations were conducted at two experimental sites on the territory of Gornata Koria. The first one is spruce-dominated and is located in the upper part of the reserve (between 1600 and $1650 \mathrm{~m}$ a.s.l.), while the second one is in mixed fir-beech stand at an average altitude in the reserve (between 1350 and $1400 \mathrm{~m}$ a.s.l.).

In Chuprene, the observations were carried out in the spruce and beech site located at the lower parts of the reserve (between 1400 and $1450 \mathrm{~m}$ a.s.l.). The surveys were made mainly in dead or in poor health stands. Particular attention was paid to xylophagous and fungal pathogens causing root and stem rot diseases.

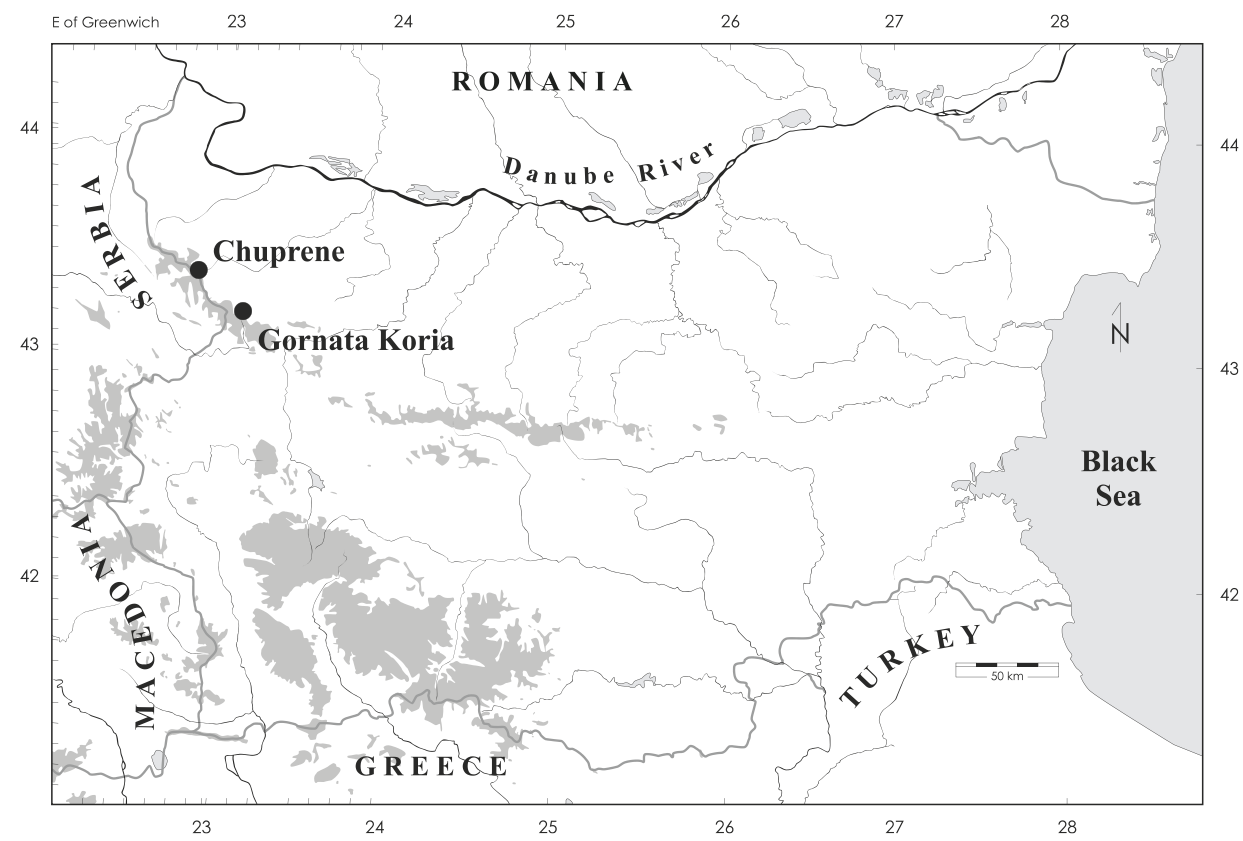

Figure I. Location of Chuprene and Gorna Koriya Reserves in Bulgaria 
Insects are identified by the presence of larvae, pupae and adults or by the type of damage to the plants used as a food source by these insects. The number of xylophagues was reported on the trunks of felled trees at sites with a size of $40 \times 20$ $\mathrm{cm}$. Damages caused by wood-destroying fungi were established by the presence of fruiting bodies on the roots, stems and branches of trees.

\section{Results}

\section{Insect pests}

In field studies, 16 insect species were identified in Gornata Koria (Table 1). Most of them were bark beetles and weevils (Curculionidae) and longhorn beetles (Cerambycidae).

The number of the most dangerous insect pest on the Norway spruce, Ips typographus, was low - the attacks were concentrated mainly in the middle part of the stems (Fig. 2A). The average number of families was $0.7 / \mathrm{dm}^{2}$, and the average number in one family was about 25 specimens. Representatives of the genus Monochamus were also found as aggressive destructive pests, attacking weakened standing trees or fallen trees that had been previously infested by bark beetles (Fig. 2B). The bark beetle Pityokteines spinidens and species of genus Pissodes were found on silver fir trees, causing destructive damages (Fig. 2C).

A part of the xylophagous insects was not considered as damaging pests. The larvae of species developed in the sapwood of dead wood, such as Trypodendron domesticum and Rhagium mordax in beech and Hylecoetus dermestoides in fir stands. Of the family Cerambycidae (Coleoptera), larvae, pupae and adults of Rhagium bifasciatum were found in semi-decomposed or decomposed wood (Fig. 2D). In addition to phytophagous insects, larvae of the predatory species with high conservation significance Cucujus cinnaberinus (Scopoli, 1763) (Coleoptera: Cucujidae) were found under the bark in spruce and fir trees (Fig. 2E).

In the field studies in the Chuprene Reserve, nine pest species of families of Coleoptera, Lepidoptera and Diptera were identified (Table 1). The terrestrial verification showed that the damages in Norway spruce stands were caused mainly by I. typographus. The number of this pest was twice as high in Chuprene as compared to its number in the Gornata Koria - about 1.7 families $/ \mathrm{dm}^{2}$ and 48 specimens per family. In the studied part in Chuprene Reserve was detected the oldest outbreak of I. typographus, with dead or newly infested trees. The pattern of attacks from I. typographus in the north-western part of the reserve was different where new (migratory) outbreaks had emerged (4-5 years ago) as a result of the high pest population.

Single spruce trees and biogroups in the upper part of the European beech belt were also strongly attacked by I. typographus as a result of physiological weakening due to competition for soil moisture with beech trees, which have a deeper and more powerful root system. 
Table I. Species composition and harmfulness of phytophagous insects in the Gornata Koria (GK) and Chuprene (CH) Reserves.

\begin{tabular}{|c|c|c|c|}
\hline Order, family, species & Plant host & Reserve & Harmfulness $^{\star}$ \\
\hline \multicolumn{4}{|l|}{ Hemiptera } \\
\hline \multicolumn{4}{|l|}{ Aradidae } \\
\hline Aradus obtectus Vasarhelyi, 1988 & Picea abies & GK & + \\
\hline \multicolumn{4}{|l|}{ Coleoptera } \\
\hline \multicolumn{4}{|l|}{ Curculionidae } \\
\hline Cryphalus piceae (Ratzeburg, 1837) & Abies alba & GK & + \\
\hline Dryocoetes autographus (Ratzeburg, 1837) & Picea abies & GK & + \\
\hline Ips typographus (Linnaeus, 1758) & Picea abies & $\mathrm{GK}, \mathrm{CH}$ & ++ \\
\hline Pissodes sp. & Abies alba & $\mathrm{GK}, \mathrm{CH}$ & ++ \\
\hline Pityokteines spinidens (Reitter, 1894) & Abies alba & GK & ++ \\
\hline Rhyncolus ater (Linnaeus, 1758) & Abies alba & GK & + \\
\hline Taphrorychus villifrons (Dufour, 1843) & Fagus sylvatica & GK & + \\
\hline Trypodendron domesticum (Linnaeus, 1758) & Fagus sylvatica & $\mathrm{GK}, \mathrm{CH}$ & + \\
\hline \multicolumn{4}{|l|}{ Lymexylidae } \\
\hline Hylecoetus dermestoides (Linnaeus, 1861) & Abies alba & GK & + \\
\hline \multicolumn{4}{|l|}{ Anobiidae } \\
\hline Ptilinus pectinicornis (Linnaeus, 1758) & Fagus sylvatica & GK & + \\
\hline \multicolumn{4}{|l|}{ Cerambycidae } \\
\hline Anastrangalia dubia (Scopoli, 1763) & Abies alba. & GK & - \\
\hline Monochamus sp. & Picea abies & GK & + \\
\hline Rhagium bifasciatum Fabricius, 1775 & Abies alba, Picea abies & GK & - \\
\hline Rhagium inquisitor Linnaeus, 1758 & Abies alba & $\mathrm{GK}, \mathrm{CH}$ & + \\
\hline Rhagium mordax (De Geer, 1775) & Fagus sylvatica & GK & - \\
\hline \multicolumn{4}{|l|}{ Lepidoptera } \\
\hline \multicolumn{4}{|l|}{ Nepticulidae } \\
\hline Stigmella tityrella (Stainton, 1854) & Fagus sylvatica & $\mathrm{CH}$ & + \\
\hline \multicolumn{4}{|l|}{ Gracillariidae } \\
\hline Phyllonorycter maestingella (Muller, 1764) & Fagus sylvatica & $\mathrm{CH}$ & + \\
\hline \multicolumn{4}{|l|}{ Erebidae } \\
\hline Calliteara pudibunda (Linnaeus, 1758) & Rubus idaeus & $\mathrm{CH}$ & + \\
\hline \multicolumn{4}{|l|}{ Diptera } \\
\hline \multicolumn{4}{|l|}{ Cecidomyiidae } \\
\hline Hartigiola annulipes (Hartig, 1839) & Fagus sylvatica & $\mathrm{CH}$ & + \\
\hline Mikiola fagi (Hartig, 1839) & Fagus sylvatica & $\mathrm{CH}$ & + \\
\hline
\end{tabular}

${ }^{\star}$ Harmfulness: - saprotroph; + slight damages; ++ severe damages (destructive pest) 


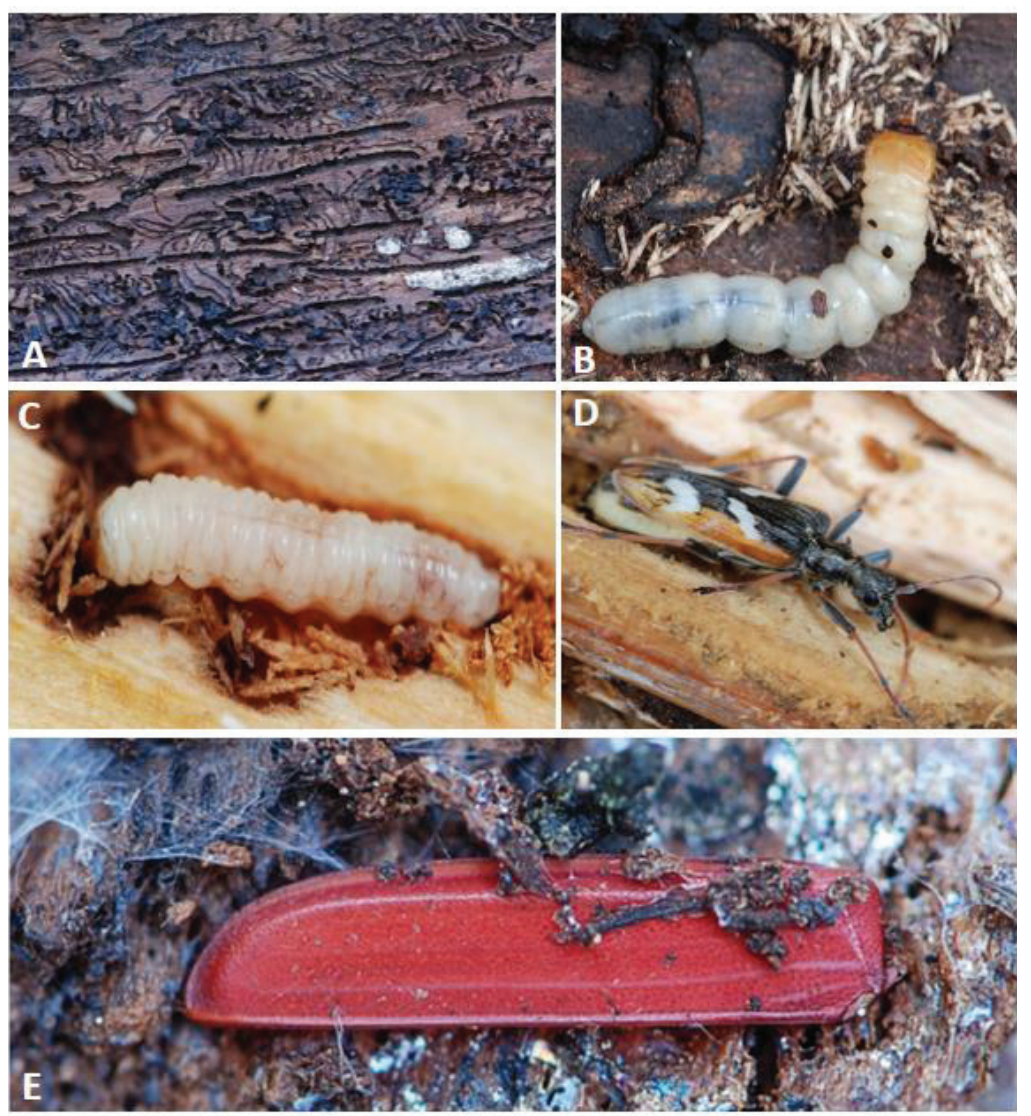

Figure 2. Insects found in Gornata Koria and Chuprene Reserves: A - larval galleries of Ips typographus; B - larva of Monochamus sp.; C - larva of Pissodes sp.; D - imago of Rhagium bifasciatum; E - elytra of Cucujus cinnaberinus.

Calliteara pudibunda was found on the leaves of raspberries (Rubus idaeus L.). The species is associated trophically with deciduous trees and shrubs.

\section{Pathogens}

During the field investigations conducted in both protected areas, ten parasitic and ten saprophytic fungal species were recorded on Norway spruce, silver fir and European beech stands in Gornata Koria and Chuprene Reserves (Table 2).

In Gornata Koria Reserve, the fungal pathogens on the stems and roots predominated. In $30 \%$ of the Norway spruce trees, rotting of the wood was found, while in silver fir - this percentage was higher - 60\%. The root rot fungus (Heterobasidion annosum) most likely caused rot in the central part of the stems. In beech, the highest percentages ( $80 \%$ of stems) were rotting in the central part, which was due to the 
Table 2. Species composition and harmfulness of fungal pathogens in the Gornata Koria (GK) and Chuprene $(\mathrm{CH})$ Reserves.

\begin{tabular}{|l|c|c|c|c|}
\hline Species & Plant host & Reserves & Plant part & Harmfulness* \\
\hline Armillaria spp. & Picea abies, Fagus sylvatica & GK, CH & root, stem & ++ \\
\hline Heterobasidion annosum & Picea abies & GK, CH & root, stem & ++ \\
\hline Fomitopsis pinicola & Picea abies & GK, CH & stem & ++ \\
\hline Fomes fomentarius & Fagus sylvatica & GK, CH & stem & ++ \\
\hline Ramaria flava & Fagus sylvatica & CH & stem & ++ \\
\hline Pholiota squarrosa & Picea abies & CH & base of stem & ++ \\
\hline Stereum rugosum & Fagus sylvatica & GK & stem & + \\
\hline Lentinellus cochleatus & Fagus sylvatica & GK & stem & + \\
\hline $\begin{array}{l}\text { Melampsorella } \\
\text { caryophyllacearum }\end{array}$ & Abies alba & GK & branches & + \\
\hline Climacocystis borealis & Picea abies & CH & base of stem & + \\
\hline $\begin{array}{l}\text { Pseudohydnum } \\
\text { gelatinosum }\end{array}$ & Picea abies & GK & stem & - \\
\hline Dacrymyces stillatus & Picea abies & GK & branches & - \\
\hline Hypoxylon fragiforme & Fagus sylvatica & GK & branches & - \\
\hline Tubifera ferruginosa & Picea abies & GK & stem & - \\
\hline Fuligo septica & Picea abies & GK & stem & - \\
\hline Stemonitis spp. & Picea abies & GK & stem & - \\
\hline Lycoperdon pyriforme & Fagus sylvatica & CH & root & - \\
\hline Mycena inclinata & Picea abies & CH & stem & - \\
\hline Gymnopilus spp. & Picea abies & CH & stem & - \\
\hline Xylaria hypoxylon & Picea abies, Fagus sylvatica & CH & stem & - \\
\hline
\end{tabular}

${ }^{\star}$ Harmfulness: - saprophagues; + weak parasite; ++ parasite (destructive pathogen)

development of Fomes fomentarius L. Fr. Fruit bodies from this fungus were found on most of the studied dead beech trees in the reserve.

Species of parasitic and saprophytic fungi were identified on the roots, stems and branches of host plants. Among the parasitic fungi, four species were the most destructive: Armillaria sp., H. annosum, Fomitopsis pinicola (Sw.) Karst. and F. fomentarius (Fig. 3A-D).

Fungal pathogens on the roots and stems caused different types of rot. For example, Armillaria sp. causes white decay on the roots and stems of many conifers and deciduous species, in which, in some cases, it develops centrally, and in others it causes peripheral rot. Heterobasidion annosum caused brown root rot of conifer stems. Saprotrophic fungi were recorded on the dead tissues of trees.

The results of the terrestrial assessments carried out at the experimental sites in Chuprene Reserve showed that the fungal pathogens causing rot disease on the stems 

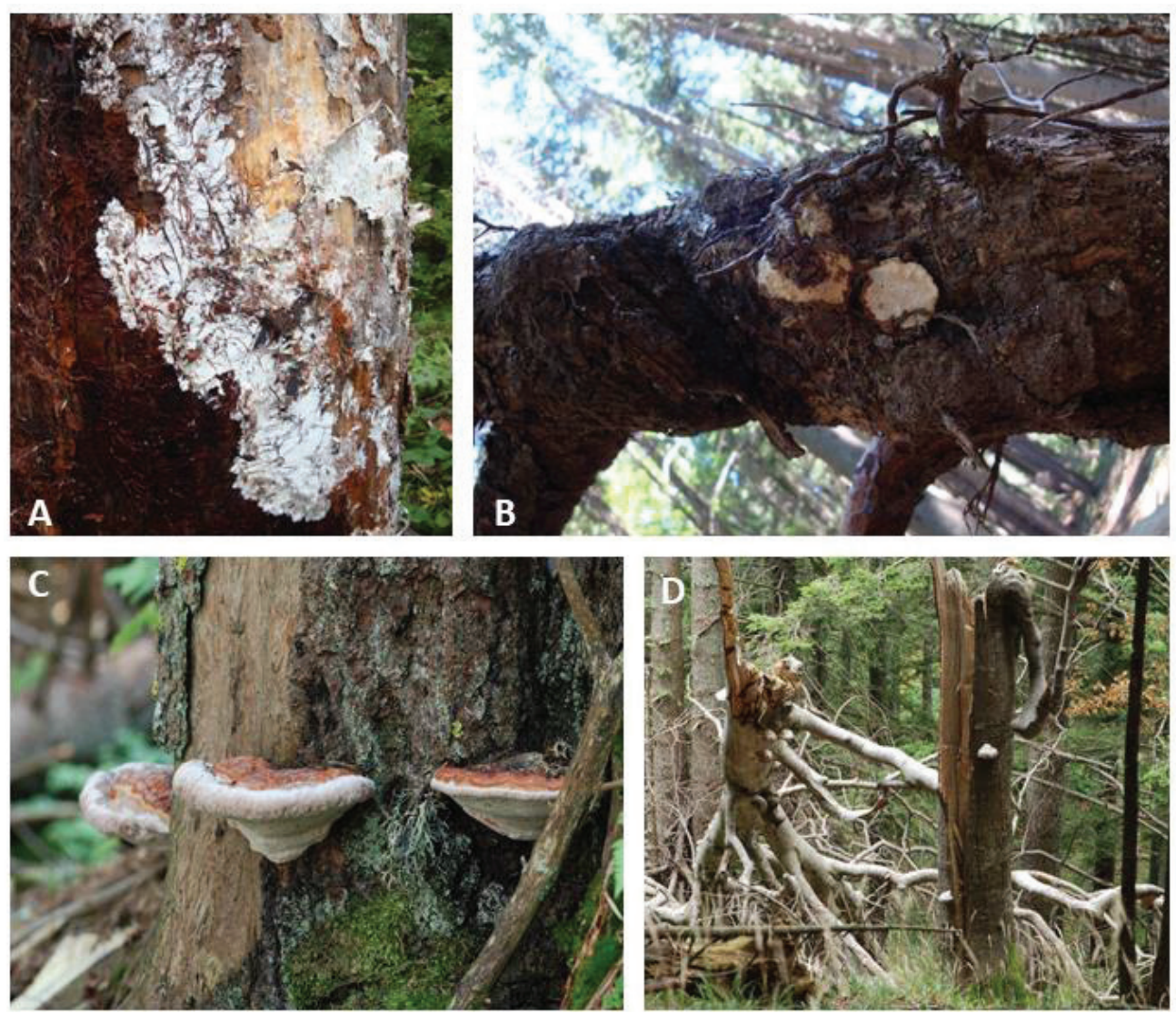

Figure 3. Parasitic fungal pathogens established in Gornata Koria and Chuprene Reserves: A - Armillaria sp.; B - Heterobasidion annosum; C - Fomitopsis pinicola; $\mathrm{D}$ - Fomes fomentarius.

and roots were very common. In $70 \%$ of the Norway spruce trees, wood rot was found. It was situated in the central part of the stems and was caused by the root fungus $(H$. annosum). In beech trees, a large percentage (75\%), of the stems was rotting in the central part, which was due to $F$. fomentarius.

In Chuprene Reserve, six species of parasites, one mycorrhizal and five saprophytic fungi were identified (Table 2). The trees infected by the fungal pathogens, which caused rot disease on the roots and stems, very often were fallen or broken. There were numerous fruit bodies of F. fomentarius on the stems of old beech trees. In addition to the recorded destructive pathogens, other pathogens - Pholiota squarrosa (Vahl) Kumm. and Climacocystis borealis (Fr.) Kotl. \& Pouzar, were identified. The mycorrhizal fungus Ramaria flava (Schaeff.) Quél. developed in the soil and the saprophytic species grew on dead tissues and organs of the host plants. 


\section{Discussion}

The expected climate changes in the European countries (long periods of drought, higher air temperatures and severe winds) will inevitably affect the phytosanitary condition of forest stands. The forecasted tendencies are toward decrease in the amount of precipitations on the territory of Southern Europe, with the most significant reduction being expected in the summer seasons. These changes are particularly unfavourable for areas with extremely steep mountainous terrain, such as the reserves Gornata Koria and Chuprene in the Western Balkan Mountain. In 2017, studies on the health condition of the Norway spruce, silver fir and European beech protected forest stands were carried out in both reserves as a part of activities included in their Management plans. A similar study had been carried out earlier in the region of the Central Balkan National Park (Zafirov et al., 2015). However, their results are not directly applicable to the same tree species in the reserves on the territory of the Western Balkan Mountain.

This study presents the utility of the applied approach, through using the capacity of the modern unmanned aerial platforms (Dimitrov et al., 2018) and traditional terrestrial entomological and phytopathological methods for complex assessment, as well as results obtained in applying an integrated model for field exploration of the phytosanitary status of two protected areas in West Balkan Range in Bulgaria - Gornata Koria and Chuprene Reserves.

In recent decades, after long periods of drought and abnormal climatic phenomena, there has been a massive drying of forests, leading to a reduction in forest stands in some area. Frequently, infection with pathogens weakens the host tree, making it susceptible to bark beetles (Ferrell, 1996). Field studies in Gornata Koria and Chuprene Reserves showed that the European bark beetle (Ips typographus) caused severe damages in natural Norway spruce forests, including dead trees, both in the protected areas and in adjacent forest stands.

The bark beetle I. typographus inhabits mainly fresh felled trees. In the presence of suitable food (trees broken by wind, snow, etc.), the pest could multiply rapidly on felled wood, after that it attacks weakened and healthy trees. In Bulgaria, I. typographus is widespread in all areas where spruce stands are distributed. Under normal conditions, the species exists at low population density and does not cause calamities. The low number of I. typographus in Gornata Koria Reserve allows trees traps to be used as effective pest control (Georgiev et al., 2013).

The decreased rainfall could affect the pathogenic fungi to a lesser extent, because a significant part of them can also develop during drought. This fact explains the established correlation between drought periods and growth of forest areas affected by fungal diseases in the studied protected areas in Gornata Koria and Chuprene Reserves. It is hypothesised that as water deficit increases for plants, some pathogenic fungi will become active and will expand their range (Roy et al., 2004; Desprez-Loustau et al., 2006). 
The wood destroying fungi identified in the Gornata Koria and Chuprene Reserves on the roots and stems of Norway spruce, silver fir and European beech stands (Armillaria sp., H. annosum, F. pinicola, P. squarrosa and F. fomentarius) have been assessed as destructive pathogens, because they damage trees' non-renewable plant tissues (Georgiev et al., 2017).

The complex of species of genus Monochamus were found in Norway spruce trees. There are three species distributed in Bulgaria (Migliaccio et al., 2007), which do not differ in larval stage: Monochamus sartor (Fabricius, 1787), M. sutor (Linnaeus, 1758) and M. galloprovincialis pistor (Germar, 1818). The first two species are trophically associated mainly with spruce trees, while the third one - with pine species. The harmfulness of Monochamus spp. is due not so much to the damage that the larvae cause to the host plants as to the fact that the imago is a proven vector of the nematode Bursaphelenchus xylophilus (Steiner, Buhrer, 1934) which is a pest on the pine trees.

In the studied protected areas not only pests have been found but also insects that have high conservation significance for the biodiversity, such as Cucujus cinnaberinus. The conservation status of the species has been noted as 'potentially endangered' in the Red List of Endangered Species of the International Union for Conservation of Nature and Natural Resources (IUCN) (Nieto et al., 2010). The larvae of C. cinnaberinus together with its adults live under the bark of various deciduous and coniferous trees (Bekchiev et al., 2017). To date, published information on sites in Bulgaria where C. cinnaberinus had been recorded included Rila, Eastern Balkan Range and Maleshevska Mountains (Gueorguiev et al., 2008).

Of particular interest for the biodiversity in the region of Western Balkan Mountains are the saproxylic species, such as Rhagium bifasciatum (Cerambycidae, Coleoptera), the larvae of which develop in semi-decomposed or decomposed wood.

\section{Conclusions}

Assessment and monitoring of health status in deteriorated forest stands in Gornata Koria and Chuprene Reserves in Western Balkan Range (Bulgaria) were conducted in 2017. An integrated approach (based on the remote sensing technologies and terrestrial validation) was applied. This method is very useful for assessment and monitoring of the health status of forests in difficult to reach and steep terrains, such as Gornata Koria and Chuprene Reserves. As a result, insect species, parasitic and saprophytic fungi were identified in the studied stands of Norway spruce (Picea abies), silver fir (Abies alba) and European beech (Fagus sylvatica). The predominant number of pests included bark beetles and weevils (Curculionidae), longhorn beetles (Cerambycidae), etc. Among the parasitic fungi, the species Armillaria sp., H. annosum, F pinicola, F. fomentarius, R. flava, P. squarrosa were identified as destructive. 


\section{References}

Angst, A., R. Rüegg, B. Forster. 2012. Declining Bark Beetle Densities (Ips typographus, Coleoptera: Scolytinae) from Infested Norway Spruce Stands and Possible Implications for Management. Psyche: A Journal of Entomology, Article ID 321084. https://doi. org/10.1155/2012/321084

Bekchiev, R., S. Beshkov, S. Arangelov, D. Kirov. 2017. Field guide for identification of animal species for assessment of forests with high conservation value. Multiprint, WWF - Bulgaria. 194 pp. (In Bulgarian).

CAB International. 2021. Ips typographus (eight-toothed bark beetle). https://www.cabi.org/ isc/datasheet/28843

Desprez-Loustau, M., Marcais, B., Nageleisen, L., Piou, D., Vannini, A. 2006. Interactive effects of drought and pathogens in forest trees. - Annals of Forest Science, 63, 597-612.

Dimitrov, S., G. Georgiev, P. Mirchev, M. Georgieva, M. Iliev, D. Doychev, S. Bencheva, G. Zaemdzhikova, N. Zaphirov. 2019. Integrated model of application of remote sensing and field investigations for sanitary status assessment of forest stands in two reserves in West Balkan Range, Bulgaria. Proceeding SPIE 11174, Seventh International Conference on Remote Sensing and Geoinformation of the Environment (RSCy2019), 1117404; https:// doi.org/10.1117/12.2532313.

Edmonds, R.L., J.K. Agee, R.I. Gara. 2011. Forest Health and Protection. Long Grove, II: Waveland Press, Inc. 667 p.

Ferrell, G. 1996. The Influence of Insect Pests and Pathogens on Sierra Forests. Sierra Nevada Ecosystem Project: Final report to Congress, vol. II, Assessments and scientific basis for management options. Davis: University of California, Centers for Water and Wildland Resources, 1177-1192.

Foley, J.A., DeFries, R., Asner, G.P., Barford, C., Bonan, G., Carpenter, S.R., Chapin, F.S., Coe, M.T., Daily, G.C., H.K. Gibbs, J.H. Helkowski 2005. Global consequences of land use. Science, 309 (5734), 570-574.

Georgiev, G., P. Mirchev, D. Doychev, M. Georgieva, P. Topalov. 2013. Control of Ips typographus (L.) (Coleoptera: Curculionidae) in Vitosha Mountain using trap trees. - Forest science, 1/2, 99-116. (In Bulgarian, English summary).

Georgiev, G., M. Georgieva, P. Mirchev, M. Zhiyanski. 2017. Main insect pests and fungal pathogens on tree and shrub vegetation in urban ecosystems. Hlorind Ltd., 54 pp. ISBN:978619-7228-04-5. Guéorguiev, B., D. Doychev, D. Ovcharov. 2008. Cucujidae (Coleoptera: Cucujoidea) - a new family to the fauna of Bulgaria. - Historia naturalis bulgarica, 19, 93-97.

Hodges, C. S. 1969. Modes of infection and spread of Fomes annosus. - Annual Review of Phytopathology, 7, 247-266.

Holdenrieder, O., M. Pautasso, P.J. Weisberg, D. Lonsdale. 2004. Tree diseases and landscape processes: the challenge of landscape and pathology. - Trends in Ecology and Evolution, 19(8), 446-452.

Nieto, A., I. Mannerkoski, A. Putchkov, P. Tykarski, F. Mason, B. Dodelin, J. Horák, S. Tezcan. 2010. Cucujus cinnaberinus. The IUCN Red List of Threatened Species 2010: 
e.T5935A11921415.http://dx.doi.org/10.2305/IUCN.UK.2010-1.RLTS.T5935A11921415. en. Downloaded on 29 June 2020.

Roy, B.A., S. Güsewell, J. Harte, J. 2004. Response of plant pathogens and herbivores to a warming experiment. - Ecology 85, 2570-2581.

Trumbore, S., P. Brando, H. Hartmann. 2015. Forest health and global change. - Science 349 (6250), 814-818.

Zafirov, N., D. Dimitrov, S. Mirchev. 2015. Dendrochronological analysis of the health status of the main tree species in the region of Central Balkan National Park. Report developed as a result of systematic monitoring of the condition of forests, provided and adopted by the Central Balkan National Park, 91 pp. 